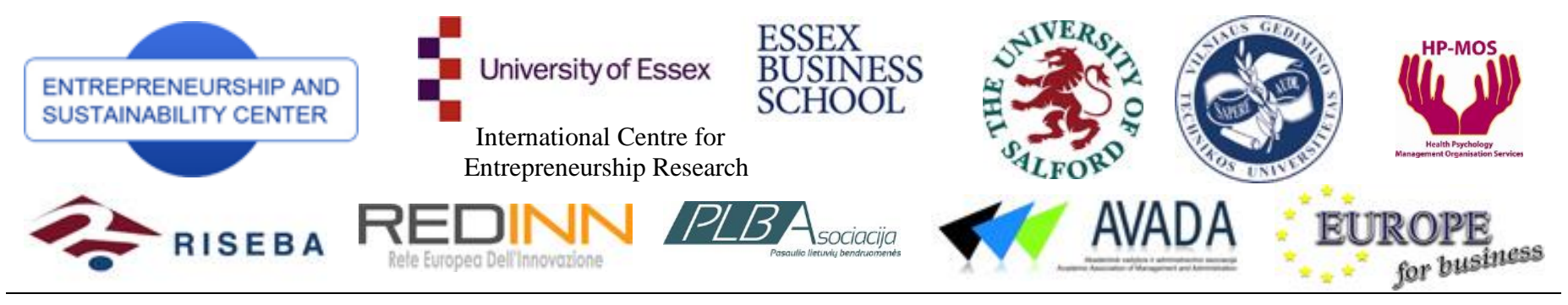

ENTREPRENEURSHIP AND SUSTAINABILITY ISSUES

ISSN 2345-0282 (online) http://jssidoi.org/jesi/aims-and-scope-of-research/

2015 Volume 3 Number 1 (September)

\title{
EXPORT AND GDP GROWTH IN LITHUANIA: SHORT-RUN OR MIDDLE-RUN CAUSALITY?
}

\section{Irina Travkina}

\author{
Vilnius Gediminas Technical University, Faculty of Business Management, Saulètekio al. 11, LT-10223 Vilnius, Lithuania
}

E-mails: irina.travkina@vgtu.lt;

Received 12 June 2015; accepted 11 August 2015

\begin{abstract}
The research paper discusses the relationship between international trade, especially export, and the economic growth, presented by GDP, in Lithuania over the period of 2000-2015 years. The analysis is started by the historical review of possible types of relationships between exports and economic growth. Furthermore, the paper presents four theoretical propositions as export-led growth (1), growth-driven export (2), a feedback relationship (3) and simple contemporaneous relationship (4). This study examines the importance of the export-led growth hypothesis for Lithuania. The testing is based on Granger causality in the export-GDP system. The export-led growth hypothesis is found in Lithuania only in the short-run. The recommendations for future investigations are developed at the end of research paper's parts.
\end{abstract}

Keywords: Granger causality, exogeneity, Lithuanian export, economic growth

Reference to this paper should be made as follows: Travkina, I. 2015. Export and GDP Growth in Lithuania: Short-run or Middle-run Causality? Entrepreneurship and Sustainability Issues 3(1): 74-84.

DOI: http://dx.doi.org/10.9770/jesi.2015.2.4(7)

JEL Classifications: F43, P45, O47

\section{Introduction}

The relationship between export (as main indicator of international trade) and GDP (as main indicator of economic growth) has long been a main subject of the scientific interest in the literature of economic development and economic growth.

Since the early 1960s policy makers and scholars have shown a great interest in the possible relationship between exports and economic growth. The motivation is clear. Should a country promote exports to speed up economic growth or should it primarily focus on economic growth, which in turn will generate exports? There are basically four theoretical propositions (Konya 2004):

1) According to the so called export-led growth hypothesis, export activity leads to the economic growth. The trade theory provides several plausible explanations in favor of this idea. Beside others, the positive impact of an outward oriented trade policy on technological change, labour productivity, capital efficiency and, eventually, on production can be mentioned. 
2) The second proposition is the growth-driven export hypothesis, which postulates a reverse relationship. It is based on the idea that economic growth induces trade flows. It can also create comparative advantages in certain areas leading to specialisation and facilitating exports.

These two approaches certainly do not exclude each other.

3) Therefore, the third notion is a feedback relationship between export and economic growth.

4) Finally, there is also potential for a simple contemporaneous relationship between these two variables.

There is a significant strand of Lithuanian scientific literature devoted to discussion on the importance of the export-led growth for small open economy countries, whose economic activities are mostly export-oriented, like in Lithuania or the other Baltic States (Travkina, Tvaronavičienè 2010, 2011, 2015; Lankauskienė, Tvaronavičienè 2014; Dudzevičiūtè et.al. 2014; Rutkauskas et.al. 2014; Vosylius et.al. 2013; Bruneckienė, Paltanavičienė 2012; Meilienė, Snieška 2010; Rojaka 2008; Ginevičius et.al. 2005; Vilpišauskas 2004; Rudzkis, Kvedaras 2003).

In the article it is assumed that export is a short-run and a middle-run source of the Lithuanian economic growth; therefore, the exports-led growth hypothesis was re-examined and re-confirmed in the case of Lithuania during the period from 2000Q1 to 2007Q4 and from 2009Q1 to 2015Q1. The article is organized as follows: firstly, the mentioned relationship should be described using information from peer-reviewed scientific sources. Secondly, the author presents the methodology and econometrical testing results. Finally, the main finding of the part should be summarized.

\section{The Analysis of the Relationship between Export and GDP}

The genesis of competitiveness, presented by the author in 2010 (Travkina, Tvaronavičienè 2010), argues that even without reference to a particular type of relationship between export and GDP, the international trade development positively influences economic growth, because it will increase capacity utilization, allow a country to take advantage of scale economies, promote technical change, and increase the resource allocation efficiency, and overall productivity as well. However, there are more theoretical insights tested by various models. The models mostly used in previous studies derive from neo-classical economic theory or from modern theories based on classical principles (Krugman 1994; Bouoiyour 2003; Travkina, Tvaronavičienė 2010; Bruneckienė, Paltanavičienė 2012; Meilienė, Snieška 2010).

Recent studies indicate that the relationship between trade and economic growth depends on the level of development (1) and economic structure (2) and is subject to an interactive process of economic development and structural change (Sun, Parikh 2001; Travkina, Tvaronavičienè 2011, 2015). However, the most recent and comprehensive survey of this literature is done by Giles and Williams (2000) who review more than one hundred and fifty applied papers on export-growth, published between 1963 and 1999. These papers fall into three groups:

a) The first group of studies is based on cross-country rank correlation coefficients;

b) the second one applies the cross-sectional regression analysis, and

c) the third group uses time series techniques on a country-by-country basis.

Two thirds of the papers belong to the third group, and more than seventy of these are based on the concept of the Granger causality and on various tests of it. Applications of causality tests and cointegration techniques in examining the relationship between international trade and economic growth have become popular since the beginning of the 1985 (Jung, Marshall 1985), especially, there has been considerable interest in testing exportled growth (ELG) using the notion of Granger causality.

Rather scarce studies exist on Lithuania, in which these techniques are applied (Rudzkis, Kvedaras 2003). In the case of Lithuania, Rudzkis and Kvedaras (2003) find evidence for export causing growth both in the long run, and in the short run. In addition, prior studies have ignored dynamic analysis, such as impulse responses, and have had gaps in their econometric procedure of applying the VAR model.

\section{The Methodology of the Testing}

Intuitive ideas can be investigated through vector autoregression models incorporating the notion of Granger or regressive causality.

This study is the subject to contribution to the scientific literature: 
a) it provides the econometric application in the proven way, to avoid misspecification and to minimize the testing bias. It includes and estimates the causal relationship by applying the three-variable VAR model based on the three time series (GDP, import, export);

b) it complements the literature on relationships between trade liberalization, economic growth and empirical evidence about the source of economic development in the case of Lithuania.

In this part the author tests the short-term and middle-term relationships between GDP, export and import for Lithuania from 2000Q1 until 2007Q4 and from 2009Q1 until 2015Q1, using a three-variable vector autoregressive (VAR) model.

The author applies econometric procedures, including the following steps:

1) Test unit root of time series;

2) Construct the three-variable VAR model;

3) VAR diagnostics;

4) Granger causality test;

5) Impulse response function.

"Eviews" program was selected as the instrument of statistical and econometric analysis as well as for testing.

\section{1) Test unit root of time series.}

The author implements the unit root test of the three time series: GDP, export and import by using the Augmented Dickey-Fuller (ADF) test (Enders 2009). If those studied series are stationary in first difference (I(1)), they will be used to construct a three-variable VAR. If some of the series, or all three, have a higher order than I(1), I will transfer them into the other forms such as logarithms, share of GDP or form of difference, and then retest the unit root. This step will cease when the transformed series are non-stationary with an order of one.

\section{2) Construction of three-variable VAR model}

VAR is the extension of the autoregressive (AR) model to the case in which there is more than one variable under study. The term „VAR“ becomes more transparent if we use matrix notation. A first order VAR in two variables would be given by (Lapinskas, 2012):

$$
Y_{t}=\alpha_{1}+\delta_{1} t+\varphi_{11} Y_{t-1}+\cdots+\varphi_{1 p} Y_{t-p}+\beta_{11} X_{t-1}+\cdots+\beta_{1 q} X_{t-q}+\varepsilon_{1 t}
$$

and

$$
X_{t}=\alpha_{2}+\delta_{2} t+\varphi_{21} Y_{t-1}+\cdots+\varphi_{2 p} Y_{t-p}+\beta_{21} X_{t-1}+\cdots+\beta_{2 q} X_{t-q}+\varepsilon_{2 t}
$$

The term „VAR“ becomes more transparent if we use matrix notation. A first order VAR in two variables would be given by

$$
\begin{aligned}
Y_{t} & =\alpha_{1}+\varphi_{11} Y_{t-1}+\varphi_{12} X_{t-1}+\varepsilon_{1 t} \\
X_{t} & =\alpha_{2}+\varphi_{21} Y_{t-1}+\varphi_{22} X_{t-1}+\varepsilon_{2 t}
\end{aligned}
$$

Where $\varepsilon_{1 \mathrm{t}}$ and $\varepsilon_{2 \mathrm{t}}$ are two white noise processes (independent of the history of $\mathrm{Y}$ and $\mathrm{X}$ ) that may be correlated (Lapinskas, 2012).

\section{3) VAR diagnostics}

To check the VAR model, the following tests should be implemented:

a) Lag order selection;

b) R-squared, adjusted R-squared, Akaike info criterion, Durbin-Watson stat.

c) VAR residual serial correlation LM test;

d) VAR residual normality test;

e) VAR residual heteroscedasticity test.

a) Lag order selection

According to Enders (2009), the model will be misspecified, when the lag length is too small. The more lags there are, the more parameters we need to estimate and the less bias in our results occur. The model will be over parameterized if the number of lags is too large. There are two approaches: lag order selection based on the LR test; and lag order selection based on Information criteria such as AIC (Akaike's Information Criterion), FPE (final prediction error), SC (Schwarz criterion), HQ (the Hannan \& Quinn (1979) criterion) (Lutkepohl 2005). 
b) R-squared, adjusted R-squared, Akaike info criterion, Durbin-Watson stat.

The popular characteristic of the model quality is the coefficient of determination R-squared. For example, $\mathrm{R}^{2}=0.65$, we say that the right-hand variables explain 65 per cent of $\mathrm{Y}^{\text {‘ }} \mathrm{s}$ variability. The problem with $\mathrm{R}^{2}$ is that this ratio can not fall when more explanatory variables are added to a model. There are many possibilities to penalize for extra explanatory variables, for example, calculation of adjusted R-squared, Akaike info criterion (AIC), Durbin-Watson stat, Schwarz information criterion (SIC). Noticeably, that sometimes these criteria (most popular among them are AIC and/or SIC) give conflicting answers: if a few models have the same left-hand variable, the best is with the smallest AIC and/or SIC.

c) VAR residual serial correlation LM, normality and heteroscedasticity tests

However, it is usual that different criteria give a different number of maximum lag lengths. The problem is which criteria we should choose. To overcome this problem, the author should run VAR with different lag orders, chosen by different criteria and the LR test, and then implement the VAR residual serial correlation LM test, residual normality and heteroscedasticity tests. An appropriate lag order needs to satisfy those tests (Nguyen 2011).

\section{4) Granger causality test}

In order to know the causality between those four time series, the author applies the Granger causality test (Enders 2009). This test detects, whether the lags of one variable can Granger-cause any other variables in the VAR system. The null hypothesis is that all lags of one variable can be excluded from each equation in the VAR system.

The basic idea of the Granger or regressive causality is that a variable X Granger causes $Y$, if past values of $\mathrm{X}$ can help explaining Y. Of course, if the Granger causality holds, this does not guarantee that X causes Y. This is why academicians say "Granger causality" rather than just "causality". Nevertheless, if the past values of X have explanatory power for the current values of $\mathrm{Y}$, it at least suggests that $\mathrm{X}$ might be causing $\mathrm{Y}$. Granger causality is the only relevant with time series variables (Lapinskas 2012).

\section{5) Impulse response function}

Based on the Granger causality test, we do not know whether or not the exports and imports have a positive effect on GDP. It is also unclear, whether or not the impact of exports on GDP is stronger than that of imports on GDP. To answer these questions, the author analyzes the impulse-response function. Shin and Pesaran defined the impulse response function as follows: "An impulse response function measures the time profile of the effect of shocks at a given point in time on the (expected) future values of variables in a dynamic system" (Shin, Pesaran 1998).

\section{Empirical Analysis and Findings}

Data set of real variables (GDP, export and import) was constructed and consisted in 41 observations through two periods: 2000Q1-2007Q4 and 2009Q1-2015Q1. The aim of this Section is to test the short-run and middlerun causality in the Granger sense. For this reason, the author uses the quarterly instead of the annual seasonally adjusted and adjusted data by working days data:

a) Gross domestic product (GDP) is GDP at prices of the current reporting period or GDP at current prices (B1GM in Eurostat database), presented in million euro;

b) Exports of goods and services (export or total export) represent the value of all goods and other market services provided to the rest of the world (P6 n Eurostat database), presented in million euro;

c) Imports of goods and services (import or total import) represent the value of all goods and other market services received from the rest of the world (P7 n Eurostat database), presented in million euro.

\section{Unit Root Test}

Table 1 reports the empirical founding of the unit root tests. In this Section, the author uses the Augmented Dickey - Fuller (ADF) technique (Enders 2009). Table 1 provides the evidence that the three time series (GDP, 
export, and import) became stationary after the first difference, excluding the GDP for the period of 2000-2007 that became stationary after the second difference.

Table 1. The empirical founding of the unit root tests

\begin{tabular}{|c|c|c|c|c|}
\hline Series & t-Stat & Prob. & Obs & Unit root in \\
\hline EX_2000Q1_2007Q4 & $-6,1066$ & 0,0000 & 30 & 1st difference \\
\hline GDP_2000Q1_2007Q4 & $-16,3034$ & 0,0000 & 29 & 2nd difference \\
\hline IM_2000Q1_2007Q4 & $-4,8705$ & 0,0005 & 30 & 1st difference \\
\hline EX_2009Q1_2015Q1 & $-3,4076$ & 0,0213 & 23 & 1st difference \\
\hline GDP_2009Q1_2015Q1 & $-3,7241$ & 0,0107 & 23 & 1st difference \\
\hline IM_2009Q1_2015Q1 & $-3,3319$ & 0,0251 & 23 & 1st difference \\
\hline
\end{tabular}

\section{VAR diagnostics}

The result from the test for the lag length criteria based on the three-variable VAR systems with the maximum lag number of 3 for the period of 2000Q1-2007Q4 quarters and of 5 lags for the period of 2009Q1-2015Q1 quarters is reported in the Appendix 1.

The results from the VAR residual serial correlation LM test, VAR residual normality test and the VAR residual heteroscedasticity test are reported in Appendixes 2-4. These three tests give support to the assumptions of our models about residuals and correct the lag order from 5 for the period of 2009Q1-2015Q1 quarters into 3 lags.

\section{Construction of three-variable VAR model}

The author constructs two VAR systems with the three endogenous variables (GDP, export, and import) for the two different periods: for the period of 2000Q1-2007Q4 quarters and for the period of 2009Q1-2015Q1 quarters. The author runs two VAR's with the lag order of 3.

VAR models are used to develop regression equations for two periods: 2000Q1-2007Q4 and 2009Q1-2015Q1:

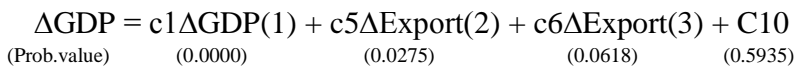

\begin{tabular}{lllr}
\hline \hline R-squared & 0.7809 & Akaike info criterion & 11.8503 \\
\hline Adjusted R-squared & 0.7535 & Durbin-Watson stat & 1.8323 \\
\hline \hline
\end{tabular}

The best regression equation that is on the right side includes gross domestic product for the period of 2000Q12007Q4 quarters as endogenous variable, describes exogenous variables with determination coefficient $\mathrm{R}^{2}$ equal to 0.7809 .

$$
\underset{\text { (Prob.value) }}{\Delta \mathrm{GDP}}=\underset{(0.0360)}{\mathrm{c} 2 \Delta \mathrm{GDP}(2)}+\underset{(0.0751)}{\mathrm{c} 4 \Delta \operatorname{Export}(1)+\underset{(0.2085)}{\mathrm{c} 6 \Delta \operatorname{Export}(3)}+\mathrm{C} 10}
$$

\begin{tabular}{lclr}
\hline \hline R-squared & 0.3084 & Akaike info criterion & 12.5651 \\
\hline Adjusted R-squared & 0.1864 & Durbin-Watson stat & 2.0044 \\
\hline \hline
\end{tabular}

The best regression equation that is on the right side includes gross domestic product for the period of 2009Q12015Q1 quarters as endogenous variable, describes exogenous variables with determination coefficient $\mathrm{R}^{2}$ equal to 0.3084 .

\section{The Granger causality test}

The Granger causality test (Pairwise Granger Causality Tests, Table 2) suggests that:

a) Data set of three real variables (GDP 2000Q1-2007Q4, Export 2000Q1-2007Q4 and Import 2000Q12007Q4) was constructed and consisted in 27 observations through the period of 2000Q1-2007Q4 quarters. 
The author fails to reject the null hypothesis of excluding GDP 2000Q1-2007Q4 from Export 2000Q12007Q4 equation at a 0.0500 significance level, due to the fact that the $\mathrm{P}$-value $=0.0399$ (as of excluding Import 2000Q1-2007Q4 from Export 2000Q1-2007Q4 equation at a 0.0500 significance level, due to the fact that the P-value $=0.0058$ ). It suggests that GDP 2000Q1-2007Q4 does not cause Export 2000Q12007Q4, and/or Export 2000Q1-2007Q4 causes GDP 2000Q1-2007Q4.

b) Data set of three real variables (GDP 2009Q1-2015Q1, Export 2009Q1-2015Q1 and Import 2009Q12015Q1) was constructed and consisted in 21 observations through the period of 2009Q1-2015Q1 quarters. The author fails to reject the null hypothesis of excluding GDP 2009Q1-2015Q1 from Export 2009Q12015Q1 equation at a 0.1000 significance level, due to the fact that the $\mathrm{P}$-value $=0.0886$ (as of excluding Import 2009Q1-2015Q1 from Export 2009Q1-2015Q1 equation at a 0.0500 significance level, due to the fact that the P-value $=0.0041$ ). It suggests that GDP 2009Q1-2015Q1 does not cause Export 2009Q12015Q1, and/or Export 2009Q1-2015Q1 causes GDP 2009Q1-2015Q1.

Table 2. The empirical founding of Pairwise Granger Causality Tests

\begin{tabular}{lcc} 
(Lags: 3$)$ & & \\
\hline Null Hypothesis: & F-Statistic & Prob. \\
\hline Export (2000-2007) does not Granger Cause GDP (2000Q1-2007Q4) & 3.28261 & 0.0399 \\
\hline Export (2000-2007) does not Granger Cause Import (2000Q1-2007Q4) & 5.46440 & 0.0058 \\
\hline Export (2009-2015) does not Granger Cause GDP (2009Q1-2015Q1) & 2.62492 & 0.0886 \\
\hline Export (2009-2015) does not Granger Cause Import (2009Q1-2015Q1) & 6.78950 & 0.0041 \\
\hline GDP (2009-2015) does not Granger Cause Import (2009Q1-2015Q1) & 8.17483 & 0.0018 \\
\hline
\end{tabular}

This conclusion needs to be compared with those from the impulse response function. However, this test does not provide information about the direction of the impact nor the relative importance between variables that simultaneously influence each other. For example, this test shows the causality of exports on GDP and also of GDP on import, and export on import.

Based on this test, the author doubts whether or not the export has a positive effect on GDP. It is also unclear, whether or not the impact of exports on import is stronger than GDP on import. To answer these questions, the author analyzes the impulse-response function.

\section{The Impulse response function}

Figures 1-4 exhibit the generalized asymptotic impulse response function. It includes 4 small figures. Each small figure illustrates the dynamic response of each target variable (GDP, export, and import) to a one-standarddeviation shock on itself and other variables. In each small figure, the horizontal axis presents the five years (or 20 quarters) following the shock. The vertical axis measures the quarterly impact of the shock on each endogenous variable.

The Granger causality test shows that export affects GDP during two periods. Figure 3.1 presents the not significant positive effect on GDP of a shock to export for the period of 2000Q1-2007Q4 quarters. Figure 3.3 presents the short-run positive effect on GDP of a shock to export for the period of 2009Q1-2015Q1 quarters. From the middle-run perspective the impact is not significant.

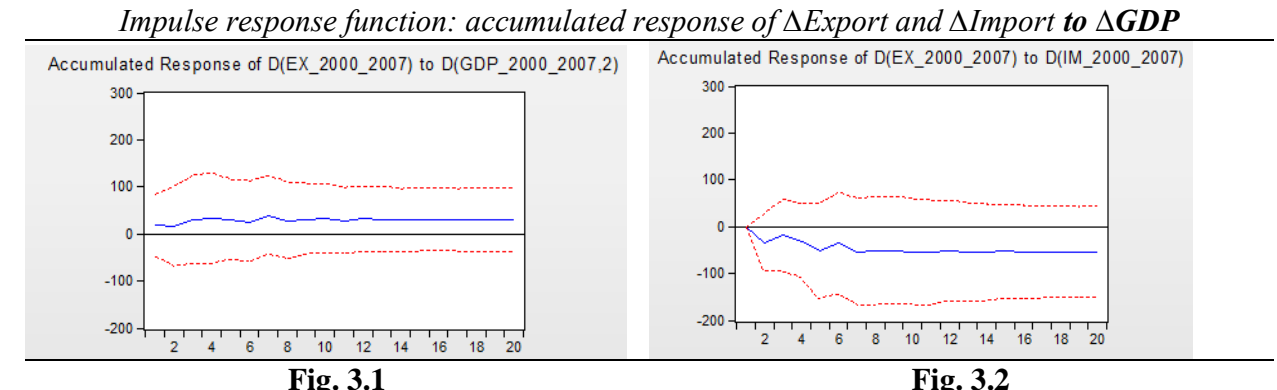




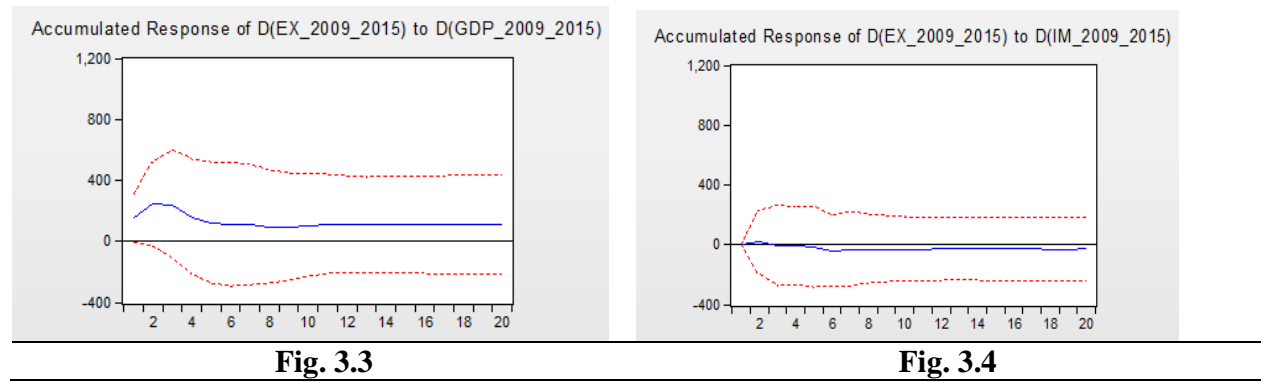

Figure 2 presents the middle-run negative effect on total import of a shock to export for the period of 2000Q12007Q4 quarters. Export does not return to its pre-shock level after the chosen period. Figure 3 suggest that export shocks have neutral impact on change of total import for the period of 2009Q1-2015Q1 quarters.

In summary impulse response is mostly consistent with Granger causality tests, except for the impact of shock to export on GDP for the period of 2000Q1-2007Q4 quarters and to export on import for the period of 2009Q12015Q1 quarters, which is more neutral.

\section{Conclusions}

This research applies two three-variable VAR models, which are constructed from the three endogenous variables of GDP, of total export and of total import in order to observe the integrated relationship between the international trade and economic growth of Lithuania during the period from 2000Q1 to 2007Q4 and from 2009Q1 to 2015Q1.

The results indicate the following aspects:

1) Export is a short-run source of the Lithuanian economic growth. The exports-led growth hypothesis was reexamined and re-confirmed in the case of Lithuania. Trade liberalization has a positive effect on the Lithuanian economic growth. The causality from trade liberalization on economic growth can be seen through export and re-export channel.

2) Export is not affected by the two other variables as GDP and import.

\section{References}

Bouoiyour, J. 2003. Trade and GDP Growth in Morocco: Short-run or Long-run Causality? Revista Brasileira de economia de Empresas Vol 3 (2): 19-26.

Bruneckienè, J.; Paltanavičienè, D. 2012. Measurement of Export Competitiveness of the Baltic States by Composite Index, Engineering Economics Vol. 23(1): 50-62. DOI: http://dx.doi.org/10.5755/j01.ee.23.1.1218.

Enders, W. 2009. Applied Econometric Time Series. 3rd Edition. New York: Published by SeriesWiley. EUROSTAT dababase. Available on the Internet: < http://ec.europa.eu/eurostat $>$.

Giles, J.A.; Williams, C.L. 2000. Export-Led Growth: A Survey of the Empirical Literature and Some Non-Causality Results. Part 1. Journal of International Trade and Economic Development Vol. 9 (4): 261-337. DOI:10.1080/09638190050086177.

Giles, J.A.; Williams, C.L. 2000. Export-Led Growth: A Survey of the Empirical Literature and Some Non-Causality Results. Part 2. Journal of International Trade and Economic Development. Vol. 9 (4): 445-470. DOI:10.1080/096381900750056867.

Ginevičius, R.; Rakauskienė, O. G.; Patalavičius, R.; Tvaronavičienė, M.; Kalašinskienė, K.; Lisauskaitė, V. 2005. Eksporto ir investiciju pletra Lietuvoje: Monografija. Vilnius: Technika.

Jung, W.S.; Marshall, P.J. 1985. Exports, growth and causality in developing countries, Journal of Development Economics Vol. 18 (1): 1-12. DOI:10.1016/0304-3878(85)90002-1.

Kónya, L. 2004. Export-led Growth, Growth-driven Export, Both or None? Granger Causality Analysis on OECD Countries, Applied Econometrics and International Development AEEADE Vol. 4 (1): 73-94. Available on the Internet: $\langle$ http://www.usc.es/economet/reviews/aeid415.pdf> 
Krugman, P.R. 1994. Competitiveness: A Dangerous Obsession, Foreign Affairs Vol. 73(2): 28-44. Available for internet: < http://www.foreignaffairs.com/articles/49684/paul-krugman/competitiveness-a-dangerous-obsession >

Lankauskienè, T.; Tvaronavičienė, M. 2014. Economy structure, productivity and economic growth: towards methodological perspective. The 8th international scientific conference "Business and Management 2014". Vilnius: Technika, 2014. ISSN 2029-4441, p. 528-535.

Lapinskas, R. 2012. Introductory econometrics II. Time series analysis. Laikines sekos. Available on the Internet: <http://uosis.mif.vu.1t/ rlapinskas/2000-2011/Praktine\%20ekonometrija\%20II/2011-2012/PE.II\%20-\%202012\%20mif.pdf>

Lutkepohl, H. 2005. New Introduction to Multiple Time Series Analysis. Berlin: Published by Springer-Verlag.

Meiliene, E.; Snieška, V. 2010. Factors of Lithuanian Industrial Competitiveness in Ex-port Policy Provisions, Public Policy and Administration Vol 31(1).

Nguyen, H.T. 2011. Exports, Imports, FDI and Economich Growth, Working Paper No. 11-03. Available on the Internet: < http://www.colorado.edu/econ/papers/wps-11/wp11-03/wp11-03.pdf>

Pesaran, H.H.; Shin, Y. 1998. Generalized impulse response analysis in linear multivari-ate models, Economics Letters Vol. 58 (1): 1729. doi:10.1016/S0165-1765(97)00214-0.

Rojaka, J. 2008. Lithuania‘s Competitiveness: Myths, Realities and Perspectives, Ekonomika Vol. 84: 92-108.

Rudzkis, R.; Kvedaras, V. 2003. Trends and econometric models of Lithuanian exports, Monetary Studies 2003(3): 29-51. Available on the Internet: 〈 http://www.lb.lt/rudzkis_1 $>$

Rutkauskas, A.V.; Stasytytè, V.; Michnevič, E. 2014. Universally sustainable develop-ment strategy for a small country: a systemic decision, Inžinerine ekonomika. Kaunas : Technologija. Vol. 25 (5): 630-537.

Sun, H.; Parikh, A. 2001. Exports, Inward Foreign Direct Investment (FDI) and Regional Economic Growth in China, Regional Studies Vol. 35 (3): 187-196. DOI:10.1080/713693805

Travkina I., Tvaronavičienė M. 2010. An Investigation into Relative Competitiveness of International Trade: the Case of Lithuania. The 6th International Scientific Conference "Busness and Management-2010”: Selected papers, Vol. 1. Ed. by R. Ginevičius, A. V. Rutkauskas, R. Počs, May 13-14, 2010, Vilnius, Lithuania. Vilnius: Technika, 504-510. DOI:10.3846/bm.2010.067.

Travkina, I.; Tvaronavičienė, M. 2011. Export competitiveness and domestic productivity facets: case of Lithuania, Journal of business economics and management. Stralsund: North-German Academy of Informatology (Stralsund). ISSN 1611-1699. Vol. 12, $2011(1), 49-68$.

Travkina, I.; Tvaronavičienė, M. 2015. Peculiarities of Export Structure in Lithuania: Synthesis and Analysis, Entrepreneurship and Sustainability Issues Vol. 2(4): 233-247. DOI: http://dx.doi.org/10.9770/jesi.2015.2.4(7).

Vilpišauskas, R. 2004. International competitiveness and the Lithuanian export policy, Monetary Studies 1: 54-69.

Vosylius, E.; Rakutis, V.; Tvaronavičiené, M. 2013. Economic growth, sustainable development and energy security interrelation, Journal of security and sustainability issues Vol. 2(3): 5-14. 
Appendix 1. Test for Lag Length Criteria

\begin{tabular}{|c|c|c|c|c|c|c|}
\hline Lag & $\log \mathbf{L}$ & $\mathbf{L R}$ & FPE & AIC & SC & HQ \\
\hline \multicolumn{7}{|c|}{ For the period of 2000Q1-2007Q4 quarters } \\
\hline 0 & $-512,5502$ & NA & $7.72 \mathrm{e}+12$ & 38,1889 & 38,3329 & 38,2317 \\
\hline 1 & $-491,7209$ & $35,4870 *$ & $3.24 \mathrm{e}+12$ & 37,3127 & $37,88859^{*}$ & 37,4839 \\
\hline 2 & $-481,8250$ & 14,6606 & $3.12 \mathrm{e}+12$ & 37,2463 & 38,2542 & 37,5460 \\
\hline 3 & $-470,2008$ & 14,6379 & $2.77 \mathrm{e}+12 *$ & $37,0519 *$ & 38,4917 & $37,4800 *$ \\
\hline \multicolumn{7}{|c|}{ For the period of 2009Q1-2015Q1 quarters } \\
\hline 0 & $-386,7498$ & NA & $1.32 \mathrm{e}+14$ & 41,0263 & 41,1754 & 41,0515 \\
\hline 1 & $-382,5292$ & 6,6641 & $2.22 \mathrm{e}+14$ & 41,5294 & 42,1259 & 41,6303 \\
\hline 2 & $-378,3381$ & 5,2941 & $4.03 \mathrm{e}+14$ & 42,0356 & 43,0794 & 42,2123 \\
\hline 3 & $-367,0630$ & 10,6817 & $4.05 \mathrm{e}+14$ & 41,7961 & 43,2873 & 42,0485 \\
\hline 4 & $-339,0239$ & $17,70892 *$ & $9.60 \mathrm{e}+13$ & 39,7920 & 41,7306 & 40,1201 \\
\hline 5 & $-305,7723$ & 10,5005 & $3.03 e+13 *$ & $37,23919 *$ & $39,62514 *$ & $37,64299 *$ \\
\hline
\end{tabular}

Appendix 2. VAR Residual Serial Correlation LM Tests

VAR Residual Serial Correlation LM Tests

Null Hypothesis: no serial correlation at lag order $h$

Sample: 2000Q1 2007Q4

Included observations: 27

\begin{tabular}{|lrrr|}
\hline Lags & \multicolumn{2}{l|}{ LM-Stat } & \multicolumn{1}{l|}{ Prob } \\
\hline & 1 & 9.029744 & $\mathbf{0 . 4 3 4 5}$ \\
\hline & 2 & 15.78249 & $\mathbf{0 . 0 7 1 6}$ \\
\hline & $\mathbf{3}$ & 14.65107 & $\mathbf{0 . 1 0 1 0}$ \\
\hline
\end{tabular}

Sample: 2009Q1 2015Q1

Included observations: 21

\begin{tabular}{|lrrc|}
\hline Lags & \multicolumn{2}{c|}{ LM-Stat } & Prob \\
\hline & 1 & 15.66124 & $\mathbf{0 . 0 7 4 3}$ \\
\hline & 2 & 14.22157 & $\mathbf{0 . 1 1 4 7}$ \\
\hline & $\mathbf{3}$ & 7.045319 & $\mathbf{0 . 6 3 2 4}$ \\
\hline
\end{tabular}

Probs from chi-square with $9 \mathrm{df}$.

Appendix 3. VAR Residual Normality Test

VAR Residual Normality Tests

Orthogonalization: Cholesky (Lutkepohl)

Null Hypothesis: residuals are multivariate normal

Sample: 2000Q1 2007Q4

Included observations: 27

\begin{tabular}{ccccc}
\hline \hline Component & Skewness & Chi-sq & df & Prob. \\
\hline \hline 1 & 0.399716 & 0.718978 & 1 & 0.3965 \\
2 & 0.128589 & 0.074408 & 1 & 0.7850 \\
3 & -0.202511 & 0.184549 & 1 & 0.6675 \\
\hline \hline Joint & & 0.977936 & 3 & 0.8066 \\
\hline \hline \multirow{2}{*}{ Component } & Kurtosis & Chi-sq & Prob. \\
\hline \hline 1 & 3.612689 & 0.422312 & 1 & 0.5158
\end{tabular}




\begin{tabular}{cccc}
2 & 2.382977 & 0.428307 & 1 \\
3 & 2.813052 & 0.039318 & 1 \\
\hline \hline Joint & & 0.889937 & 3 \\
\hline & & & \\
Component & Jarque-Bera & df & Prob. \\
\hline \hline 1 & 1.141290 & 2 & 0.5652 \\
2 & 0.502716 & 2 & 0.7777 \\
3 & 0.223867 & 2 & 0.8941 \\
\hline \hline Joint & 1.867873 & 6 & 0.9314 \\
\hline \hline
\end{tabular}

VAR Residual Normality Tests

Orthogonalization: Cholesky (Lutkepohl)

Null Hypothesis: residuals are multivariate normal

Sample: 2009Q1 2015Q1

Included observations: 21

\begin{tabular}{ccccc}
\hline \hline Component & Skewness & Chi-sq & df & Prob. \\
\hline \hline 1 & -0.307635 & 0.331237 & 1 & 0.5649 \\
2 & 0.009771 & 0.000334 & 1 & 0.9854 \\
3 & 0.907170 & 2.880353 & 1 & 0.0897 \\
\hline \hline Joint & & 3.211924 & 3 & 0.3601 \\
\hline \hline Component & Kurtosis & Chi-sq & Prob. \\
\hline \hline 1 & 2.218174 & 0.534845 & 0.4646 \\
3 & 2.889712 & 0.010643 & 0.9178 \\
Joint & 4.588915 & 2.209069 & 1 & 0.1372 \\
\hline \hline Component & & 2.754557 & 1 & 0.4310 \\
\hline \hline 1 & Jarque-Bera & df & 3 & \\
\hline \hline Joint & 0.866082 & 2 & Prob. & \\
\hline \hline & 0.010977 & 2 & 0.6485 & \\
\hline \hline
\end{tabular}


Appendix 4. VAR Residual Normality Heteroskedasticity Tests

VAR Residual Heteroskedasticity Tests: No Cross Terms (only levels and squares)

Sample: 2000Q1 2007Q4

Included observations: 27

\begin{tabular}{|c|c|c|c|c|c|}
\hline \multicolumn{3}{|l|}{ Joint test: } & & & \\
\hline Chi-sq & df & Prob. & & & \\
\hline 90.38522 & 108 & 0.8896 & & & \\
\hline \multicolumn{6}{|c|}{ Individual components: } \\
\hline Dependent & R-squared & $\mathrm{F}(18,9)$ & Prob. & Chi-sq(18) & Prob. \\
\hline res $1 *$ res 1 & 0.440506 & 0.349925 & 0.9694 & 11.89367 & 0.8527 \\
\hline res $2 *$ res 2 & 0.571213 & 0.592071 & 0.8308 & 15.42275 & 0.6328 \\
\hline res3*res3 & 0.651409 & 0.830529 & 0.6495 & 17.58804 & 0.4831 \\
\hline res $2 *$ res 1 & 0.469880 & 0.393940 & 0.9520 & 12.68676 & 0.8098 \\
\hline res3*res1 & 0.647517 & 0.816453 & 0.6600 & 17.48297 & 0.4902 \\
\hline res3*res2 & 0.491346 & 0.429321 & 0.9350 & 13.26634 & 0.7755 \\
\hline
\end{tabular}

Sample: 2009Q1 2015Q1

Included observations: 21

\begin{tabular}{|c|c|c|c|c|c|}
\hline \multicolumn{3}{|l|}{ Joint test: } & & & \\
\hline Chi-sq & $\mathrm{df}$ & Prob. & & & \\
\hline 111.8809 & 108 & 0.3797 & & & \\
\hline \multicolumn{6}{|c|}{ Individual components: } \\
\hline Dependent & R-squared & $\mathrm{F}(18,9)$ & Prob. & Chi-sq(18) & Prob. \\
\hline res1*res1 & 0.902680 & 1.030597 & 0.6021 & 18.95628 & 0.3945 \\
\hline res $2 *$ res 2 & 0.873025 & 0.763952 & 0.7054 & 18.33353 & 0.4339 \\
\hline res $3 *$ res3 & 0.982369 & 6.191006 & 0.1479 & 20.62975 & 0.2985 \\
\hline res $2 *$ res 1 & 0.938168 & 1.685864 & 0.4370 & 19.70152 & 0.3499 \\
\hline res3*res1 & 0.736624 & 0.310761 & 0.9361 & 15.46910 & 0.6295 \\
\hline res $3{ }^{*}$ res 2 & 0.741592 & 0.318872 & 0.9322 & 15.57343 & 0.6223 \\
\hline
\end{tabular}

Irina TRAVKINA - lecturer at the Department of Economics and Management of Enterprises at Vilnius Gediminas Technical University. Research interests: international trade, competitiveness, economic growth.

This is an open access journal and all published articles are licensed under a

Creative Commons Attribution 4.0 International License

Copyright of Journal "Entrepreneurship and Sustainability Issues" (C) Entrepreneurship and Sustainability Center, All Rights Reserved 